\title{
The Urbanization and Growth of Malaysia: Case Study of Iskandar Region
}

\author{
Muhammad Yazrin Yasin ${ }^{1,2}$, Jamalunlaili Abdullah ${ }^{2}$, Mariney Mohd Yusoff ${ }^{1}$ and Norzailawati Mohd Noor ${ }^{3}$ \\ ${ }^{1}$ Department of Geography, University of Malaya,50603 Kuala Lumpur, Malaysia. \\ ${ }^{2}$ Faculty of Architecture, Survey and Planning, Universiti Teknologi MARA, 40450 Shah Alam, Malaysia. \\ ${ }^{3}$ Kuliyyah Architecture and Environmental Design, International Islamic University of Malaysia, 50728 Kuala Lumpur \\ Malaysia.
}

Correspondence: Muhammad Yazrin Yasin : yazrinyasin@gmail.com

Received: February 02, 2021;

Accepted: February 09, 2021;

Published: 04 March 2021

\begin{abstract}
This paper discusses the process of economic growth and urbanization in Malaysia, the contribution of Johor in the nation's growth and the development of Iskandar Malaysia. First, we explore the range of institutions that engage in urban and regional planning at various level and their respective statutory development plan. Next, we present the contextual of the south Johor particularly Iskandar region and the new administrative of Iskandar Puteri. The development of Iskandar region is intended to benefit all in south Johor and by coordinating the efforts of various Government agencies, Iskandar Regional Development Authority (IRDA) is helping locals share the benefits of economic growth. Afterwards, we evaluate some issues that have arisen with regard to the physical development and the statutory development plans in Johor and Iskandar region on urbanization and urban growth pattern. From the analysis, we identified that among issues aroused are the absence of urban growth boundary within Iskandar region; land use change and agricultural land encroachment; low density and mixed-use development and environmental change and degradation.
\end{abstract}

\section{Introduction}

Malaysia is a country strategically located in the center of South East Asia. Since its independence in 1957, the country has been developing rapidly. There is a need to examine how urban and regional planning trough national physical plan, state structure plan, regional and local plan developed and assumed center stage in environmental change concept, particularly in land use planning and urban growth pattern. Because of the diversity of urban area, understanding urban growth pattern is a major challenge for urban planners and managers. The complexity of urban environment, social necessitate and economic anxiety requires an attentive development plans with a sustainable urban growth policy [1]. Conventionally, the development plans were used as the main tools for urban growth management. Thus, the role of the national development and planning framework is essential in achieving a sustainable and holistic ecosystem.

The second highlight is to present the contextual of the south Johor particularly Iskandar region and the new administrative of
Iskandar Puteri. The development of Iskandar region is intended to benefit all in south Johor and by coordinating the efforts of various Government agencies, Iskandar Regional Development Authority (IRDA) is helping locals share the benefits of economic growth. IRDA was formed under the IRDA Act 2007, Act 664 to provide proper direction, policies and strategies in relation to the development of Iskandar region (see Figure 1). This is achieved through previous Comprehensive Development Plan (CDP) 20062025 [2], which was prepared by Khazanah Nasional to guide IRDA to work hand in hand with all relevant planning authorities to develop Iskandar region. The revised CDP ii 2014-2025 ensures all planning strategies remain relevant to the people of Johor in general and Iskandar in specific.

Lastly, this paper explores some issues that have arisen with regard to the physical development and the statutory development plans in Johor and Iskandar region on urbanization and urban growth pattern. Among issues aroused are: the absence of urban growth boundary within Iskandar region; land use change and agricultural land encroachment; low density and mixed use development and environmental change and degradation. 


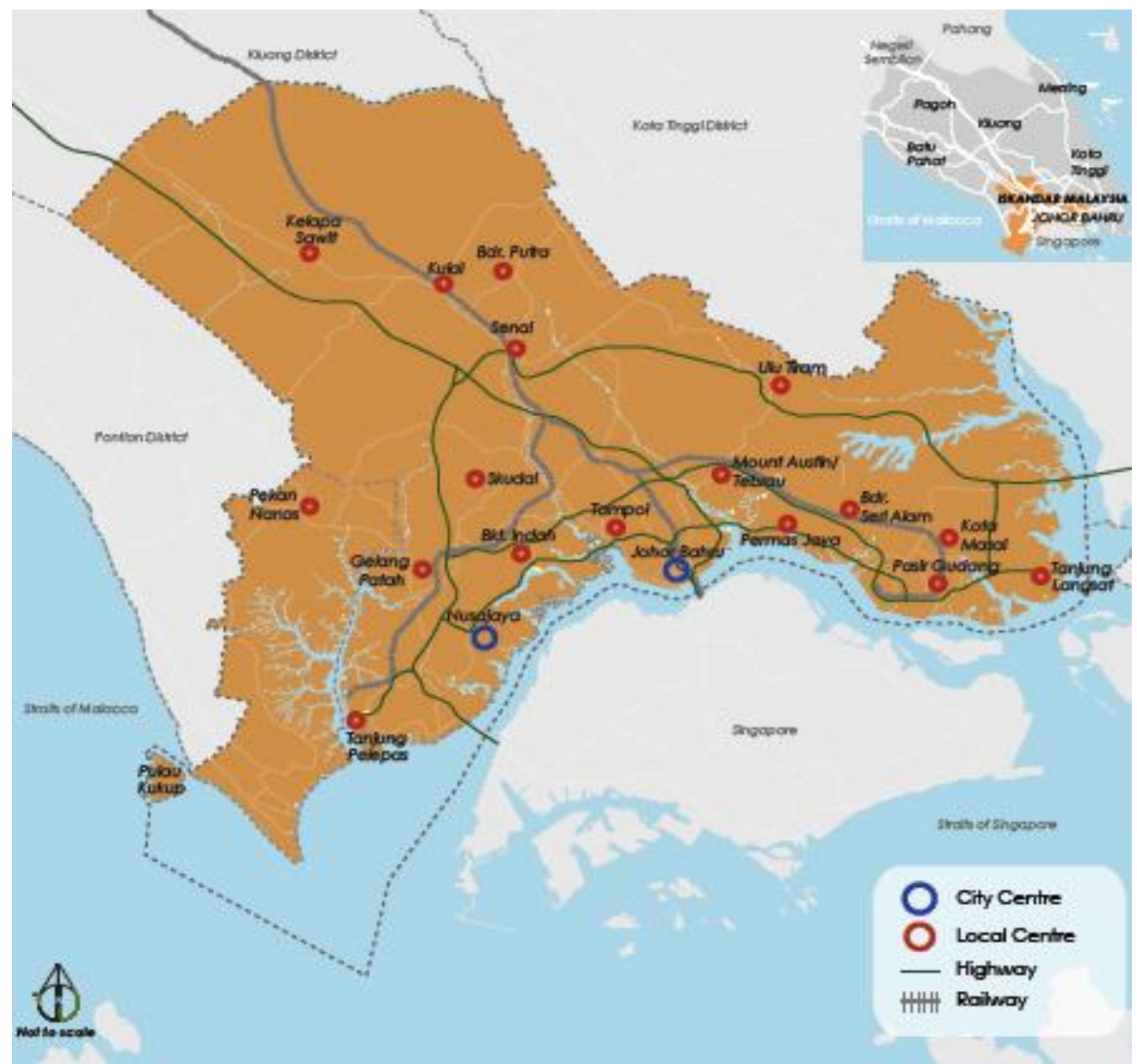

Figure 1: Iskandar region is consisting of 9 local government authorities in south Johor [2].

\section{Urban planning institutions and statutory development plans}

The early urban planning practices in Malaysia are based on the Crown colony during British occupation and it goes way back in 1912. Six decade later, a new and improve town and country planning was established with the passing of Town and Country Planning Act 1976 (Act 172) that elaborate the power of the federal and the state governments. The system was very similar to the one that has been practice in England and Wales, where structure plan and local plan are the tools for urban growth and development control. Today, the Department of Town and Country Planning also known as Plan Malaysia is the governing body of the execution of Act 172 in the Federal and States of peninsular Malaysia. The mission of the department is to spur national physical planning through the implementation of comprehensive, systematic and innovative development planning for the well-being of society.

Physical planning in this context is referring to the national development planning framework, comprises of 3 stages. The first stage is the strategic development planning of the nation, steered by the Five-Year Malaysia Plan as the highest strategic planning document. The vision of the Five-Year Malaysia Plan is to balance economic growth and fiscal consolidation initiatives to ensure continuous and inclusive development without impairing growth prospects (see Figure 2) [3]. Although the National Physical Plans is not part of the Five-Year Malaysia Plan, but the former must correspond and in accordance with the latter ${ }^{[4]}$. Other policies such as monetary, socioeconomic, human capital etc. must be consistent with the Five-Year Malaysia Plan. This initial stage, however, are established also to determine the extension and direction of physical and land use planning to the regional or state and local level.

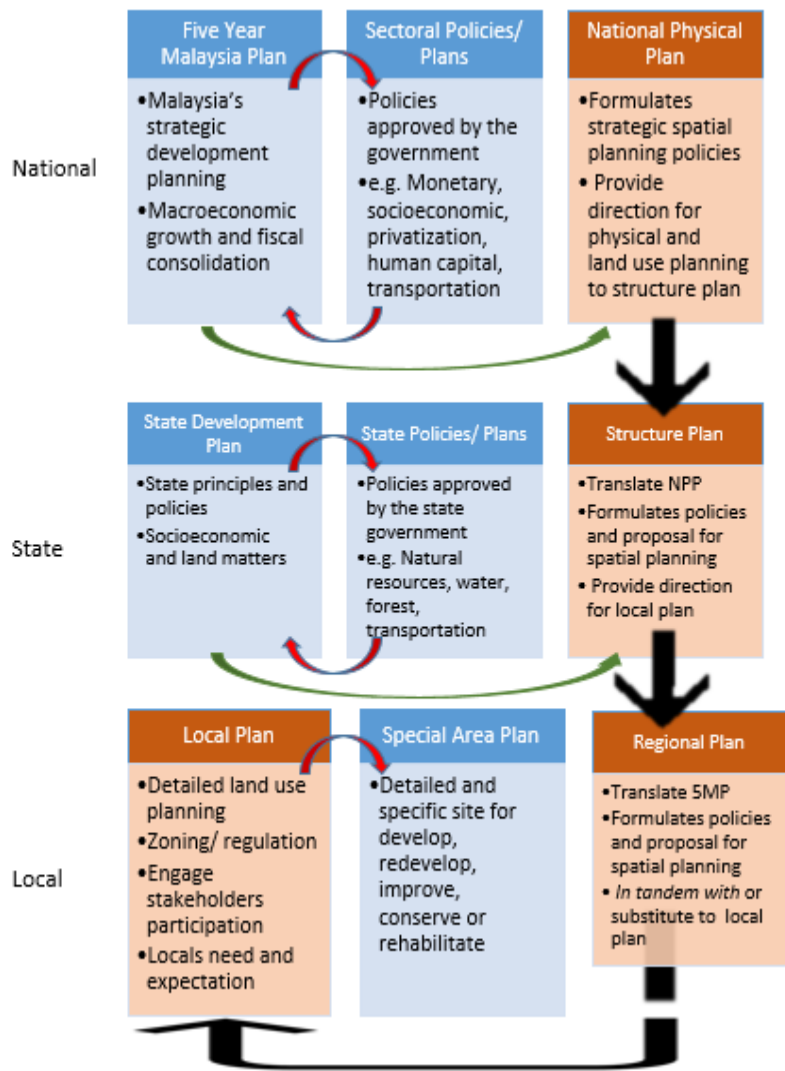

Figure 2: The national development planning framework and the statutory development plans. Adapted from ${ }^{[3]}$. 
The National Physical Plan (NPP) was initiated as a result of the amendment of Act 172 in 2001 . The act stated that NPP is a written statement formulating strategic policies for the purpose of determining the general directions and trends of the physical development of the nation. The National Physical Planning Council (NPPC) is the body that regulate the NPP, chairs by the Prime Minister and the Director General of Plan Malaysia are the secretary of the council. Although according to Section 2A ${ }^{(1)}$ of Act 172, the head executive of state governments are members of the council, the council (NPPC) can only advise and negotiate with the state governments, as the town and country planning is under the concurrent list of the Federal Constitution. Also, in Section 6B (4) the NPP is required by the act to have a 5-year revision to in tandem with the review of the Five-Year Malaysia Plan.

The lower stage in the framework is the State Structure Plan (SSP) and other state policies regulated by the respective state government, without inadvertently contemplating the economic and physical policies that were set from the top. The SSP is virtuous as long as it does not contradict with the state development plan and state policies under the State List of the federal Constitution. SSP is a state statutory planning document that provide a guideline and control over state physical development. SSP has a long list of current state policies binding to the document. For example, the previous Selangor State Structure Plan 2020 has included 104 policies for economic development ${ }^{(21)}$; social development ${ }^{(11)}$; physical development and environment ${ }^{(68)}$; and planning and delivery ${ }^{(4)}$.

The head executive of the state governments, the Menteri Besar chairs the State Planning Committee (SPC) which play a role as the secretariat that produced and gazette the SSP assembled by the respective state Town and Country Planning Department in Peninsular Malaysia. Just like NPP, the SSP is required by the act to have a 5-year revision to ensure its alignment to the latest policies, plans and strategic both at the national and the state level. Essentially, three things that SSP must not disregard are:

(i) Specified and implicated the state policies and strategic plans regarding:

a. Urban and rural land use and development planning.

b. Ways to improve the natural and manmade environment.

c. Roads and transport networks planning and management.

d. Ways to achieve sustainable socioeconomic growth and wellbeing.

(ii) Any directive or policy statement determined or directed by the state planning committee or national physical planning council in specific or special matters or issues;

(iii) Specified any significance relation and effects of the above policies, plans, matters or issues to other development plans of the neighboring states or regions.

In parallel, the planning framework has another requirement for regional planning committee under subsection $6 \mathrm{~A}(5)(\mathrm{b})$ of the Act 172 called the regional plans. Although commonly the regional authority has more than one state that need interstate cooperation to tackle significant strategic matters of regional concerns jointly, exception for regional authority in Johor, Sabah and Sarawak to produce regional plans considering they were one state growth conurbation. Regional plan consists of spatial policies and broad development strategies to guide and coordinate development including key regional infrastructure provision such as highways, ports and airports. Since the regional planning authority is established by the federal government, funding and financial assistance from the federal government has become a conventional practice to accelerated development in these economically lagging regions. Thus, most of their policies and proposals for spatial planning is a translation of Five-Year Malaysia Plan if not less. Regional planning authorities also generated their own income through foreign direct and strategic investments.

At the nethermost stage where the service delivery is the frontline, local plan is the ultimate guidance that focus on social, economic and environmental of the confined jurisdiction. The Local Plan is prepared with a disposition of translating the policies and strategies of SSP with more specific development proposal and building and land use control of a local authority. Just like NPP and SSP, local plan is a requirement by Act 172 that consists of

i. A spatial translation of national and state strategies, policies and plans onto physical and social development;

ii. A written statement of land use planning and development, including the most sustainable ways to develop potential land, mitigate environmental degradation, rehabilitating topography and natural landscape, preserve and improvise urban designs, providing ample infrastructures and transport networks;

iii. A key diagram in a form of an overall land use planning map supported by layers of maps of urban and rural use (growth centers, boundaries, limits), zones (residential, industrial, commercial, environmentally fragile), physical development (infrastructures, telecommunications, utilities, public amenities, recreations, public transportations), and other concerned matters.

Conversely, the role of planning institution and the statutory development plans function to determine the extension and direction of physical and land use planning to the regional or state and local level. Through the provision of the statutory plans via the Act, the planning institutional legalized the document as main reference on urbanization process. To further enhance the role of planning institution and the statutory development plans, and to meet with continuous urban and economic growth, the national development planning framework requires in built system of big data for reviewing, monitoring and projecting growth. This is due to the amount of physical and geographical information such as satellite images, land use land cover data, maps and other geospatial attributes that need to be retrieved, processed and analyzed to produce statutory development plans. Therefore, all the policies, strategies, regulations, procedures stated in the statutory plans should be embraced by all stakeholders in urbanization process in Malaysia.

\section{Malaysia's economic growth and urbanization}

Malaysia has enjoyed a spurring economic growth and development at its peak since 1970 s to 2000 s (Table 1). In the 1970s, Malaysia used to rely on agricultural and mining which put them in resource-based and fragile economy. Over many years, it has developed and transformed into manufacturing and international trade. Gradually service oriented industry such as tourism, financial and high-tech manufacturing has greatly changed Malaysia's economic and positioned them as one of tiger cub of Asia. At present, Malaysia is pulling it best resources and human capital to become a knowledge-driven and innovation-based economy. 
Table 1: Malaysia economic transformation 1960s $-2010 \mathrm{~s}^{[5,6]}$.

\begin{tabular}{|l|l|l|l|l|l|l|}
\hline $\mathbf{1 9 6 0 s}$ & $\mathbf{1 9 7 0 s}$ & $\mathbf{1 9 8 0 s - 1 9 9 0 s}$ & $\mathbf{2 0 0 0 s}$ & 2010s \\
\hline $\begin{array}{l}\text { Agricultural \& } \\
\text { mining }\end{array}$ & $\begin{array}{l}\text { Primary } \\
\text { industries }\end{array}$ & Export oriented & Services & High-tech services & Knowledge-driven & Innovation \\
\hline $\begin{array}{l}\text { Timber, rubber, } \\
\text { tin, forestry }\end{array}$ & $\begin{array}{l}\text { Commodity, } \\
\text { Manufactur-ing } \\
\text { and domestic } \\
\text { production }\end{array}$ & $\begin{array}{l}\text { Oil \& Gas } \\
\text { FDI driven } \\
\text { investment } \\
\text { High-tech production } \\
\text { Trade }\end{array}$ & $\begin{array}{l}\text { Hospitality, } \\
\text { Hotel, } \\
\text { Financial }\end{array}$ & $\begin{array}{l}\text { Operations and IT } \\
\text { hub, } \\
\text { Outsourcing and } \\
\text { shared services }\end{array}$ & $\begin{array}{l}\text { Business hub and } \\
\text { entre of } \\
\text { excellence }\end{array}$ & $\begin{array}{l}\text { High value } \\
\text { business } \\
\text { function } \\
\text { IR 4.0 }\end{array}$ \\
\hline
\end{tabular}

By and large, the last half century has been a period of economic prosperity and urban growth for Malaysia. However, the initial driver that propelled early economic development and urban agglomeration for Malaysia was tin mining and rubber plantation [7]. Large tin deposits were found in Perak and Selangor, making settlements of miners fast growing and becoming mining towns. Rubber plantations also contributed to workers estate, then agglomerate into small growth center. Even Kuala Lumpur was founded by tin miner and trader called Sutan Puasa ${ }^{[8]}$. Then the prominent economic landscape was gradually changing in the 1970s into commodity based particularly palm oil. Palm oil was brought in by the British government in the 1870 s, but the mass plantations and production begins a century later. The government under a statutory body named Federal Land Development Authority or FELDA has open many new settlements in the 1970s which was part of new rural development scheme. The FELDA scheme was introduced to help rural poor into newly cleared areas for cash crops and other range of economic development.

Late 1970 s or early 1980 s has witnessed the transition from agricultural economy to industrial based. With the support of National Industrial Policy and Industrial Master Plan, manufacturing and domestic production achieved remarkable growth ${ }^{[9]}$. Many factories and warehouses were built in the suburban areas. The rural migration was prompted at this point and many new settlements was built, creating industrial districts mostly concentrated in Penang, Selangor, Johor and Melaka. This has cause divided urbanization rate among the states (Table 2). Growing in manufacturing and domestic production has changed and improved overall urban infrastructures, logistics, employment and economic growth ${ }^{[9]}$. The spillovers of manufacturing industries have direct impact involve land use changes - when the land is converted from some rural use to urban one. It can be concluded that with an effective industrial policy, manufacturing industries will drive long term growth of nation and spur urbanization.

Table 2: Malaysia's Federal Territory and state urbanization rate 1970-2010 [10].

\begin{tabular}{|l|l|l|l|l|l|}
\hline $\begin{array}{l}\text { State/ Federal } \\
\text { Territory* }\end{array}$ & \multicolumn{2}{|l|}{ Year } \\
\cline { 2 - 6 } & $\mathbf{1 9 7 0}$ & $\mathbf{1 9 8 0}$ & $\mathbf{1 9 9 0}$ & $\mathbf{2 0 0 0}$ & $\mathbf{2 0 1 0}$ \\
\hline Johor & 26.3 & 35.2 & 47.8 & 63.7 & 72.0 \\
\hline Kedah & 12.6 & 22.5 & 32.5 & 38.8 & 64.3 \\
\hline Kelantan & 15.1 & 28.1 & 33.5 & 33.5 & 41.5 \\
\hline Melaka & 25.1 & 23.8 & 38.7 & 67.4 & 86.5 \\
\hline Negeri Sembilan & 21.6 & 32.6 & 42.0 & 55.0 & 65.9 \\
\hline Pahang & 19.0 & 26.1 & 30.4 & 42.1 & 51.0 \\
\hline Perak & 27.5 & 33.8 & 53.6 & 59.0 & 69.2 \\
\hline Perlis & 0.0 & 8.9 & 26.6 & 33.8 & 51.8 \\
\hline Penang & 51.0 & 47.5 & 75.0 & 79.5 & 90.6 \\
\hline Sabah & 16.9 & 19.9 & 33.2 & 48.1 & 53.3 \\
\hline Sarawak & 15.5 & 18.0 & 37.5 & 48.0 & 53.2 \\
\hline Selangor & 45.6 & 40.9 & 75.2 & 88.1 & 91.4 \\
\hline
\end{tabular}

\begin{tabular}{|l|l|l|l|l|l|}
\hline Terengganu & 27.0 & 42.9 & 44.5 & 49.4 & 59.1 \\
\hline Kuala Lumpur* & - & 100.00 & 100.00 & 100.00 & 100.00 \\
\hline Labuan* & - & 46.3 & 48.4 & 72.26 & 81.8 \\
\hline Putrajaya* & - & - & - & 62.8 & 100.00 \\
\hline
\end{tabular}

Then, in the 1990s, with the continuation of Industrial Master Plan 2 , but the focus is on bridging an integrated industrial networks and cluster development that consists of high technology production and business development strategy ${ }^{[9]}$. Petroleum and petrochemical industries have also evolved, through integration with manufacturing sectors and hi-tech production. The government has also initiated a cluster-based development of information technology and multimedia industries of Multimedia Super Corridor (now known as MSC Malaysia) in 1996. This has further placed a direct effect on urban growth and land development because high tech industries require proximity of knowledge sources, so they can exploit and benefit from. For example, an R\&D specialized firms would benefit from research university presence, in acquiring specific knowledge and human capital.

In the new millennium, Malaysia has promoted the county to transform into high tech services as the new source of economic growth. The persistence development of MSC Malaysia and the National Information Technology Agenda has paid off when the industrial has reached a competitive strength, built upon relatively low labor cost, sound physical and policy infrastructure, fairly educated workforce, availability of support services, and spearhead by foreign direct investment ${ }^{[11]}$. At this stage, the concentration of development has focused in the urban areas, especially in the national and regional conurbation. The economic transformation has affecting land use change, for need of housing and other urban amenities. Many firms and business have moved to the suburbs provided it is greatly connected and high accessibilities and results in urban expansion.

A study by Hassan and Nair ${ }^{[10]}$ has confirmed the relationship between rapid urbanization and the economic transformation, knowledge-based development and persistent government policies and strategies. The shift from agriculturally based into industrial based and then into knowledge based economic has driven a rapid increase in urban growth in towns and cities throughout the country. The level of urbanization in Malaysia has never slowed down since 1970 with every decade shows utmost increase from $26.8 \%$ in 1970 to $70.9 \%$ in 2010 (Table 3). This goes along with the extreme increment of urban population by $557.5 \%$ or 16 million. The average population growth rate however shows a contrasting figure with decreasing rate every 10 years. The most likely causes are the instantaneous rate of urban spatial growth and changes in towns and cities boundaries.

Table 3: Malaysia's urbanization and population growth rate 1970-2010 [10].

\begin{tabular}{|l|l|ll|}
\hline Year & Urbanization & Average population growth \\
\hline
\end{tabular}




\begin{tabular}{|l|l|l|}
\hline & rate $\mathbf{( \% )}$ & rate $(\boldsymbol{\%})$ \\
\hline 1970 & 26.8 & - \\
\hline 1980 & 35.8 & 5.2 \\
\hline 1990 & 50.7 & 5.1 \\
\hline 2000 & 61.7 & 4.8 \\
\hline 2010 & 70.9 & 3.5 \\
\hline
\end{tabular}

According to PwC Malaysia ${ }^{[12]}$, from 1990s to 2010s, Malaysia's economy compare to most other ASEAN countries were strong and resilient, despite the effect of the global economic downturn. Malaysia is also a large trading partner of intermediary goods to China and are currently Southeast Asia's third largest economy by GDP after Indonesia and Thailand. Manufacturing grew at $4.3 \%$ and contributing to year-on-year growth of $4.9 \%$.

Forecasted growth seems way better and the economist is positive that it is on track to achieve a fully developed nation in 2025. Malaysia's GDP per capita has reach a high $60 \%$ of the average OECD countries, and projected to continue climbing (Figure 3). This will eventually have an effect on the extension and direction of urbanization in Malaysia.

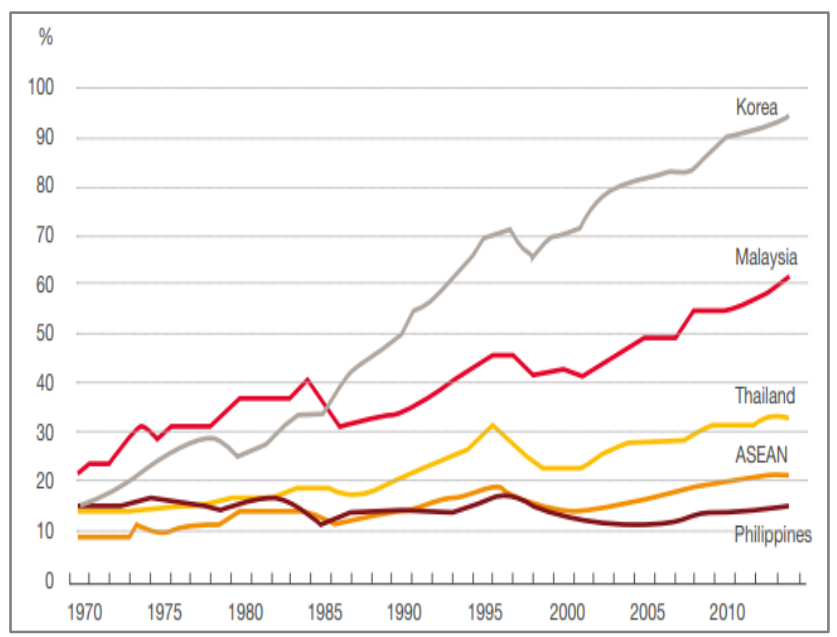

Figure 3: Malaysia's economy compare to OECD average GDP per capita as a proportion of the OECD average [12].

\section{Urbanization and Growth of Johor}

The history of urbanized Johor, in particular Kota Johor Lama had begun as early as the 16th century. The Sultan of Johor has announced Kota Johor Lama as the capital of Johor in 1540 and built his palace and fortress as tactical measures against Portuguese, Aru, Acheh and Siak ${ }^{[13]}$. The state has already achieved cultural, social, architecture, nature and aesthetic values in the early built environment particularly their township. Then in 1855 Tanjung Puteri was pronounced as the capital of Johor replacing Teluk Belanga, due to urban expanding driven by social and economic growth particularly in modern irrigating and agriculture. It was the birth of the modern state of Johor and Tanjung Puteri was renamed Iskandar Puteri (in 1859). It was again renamed Johor Bahru in 1866. The Chinese settlement in Skudai, Tebrau and Sungai Danga was opened creating an urbanized triangle (Figure 4).

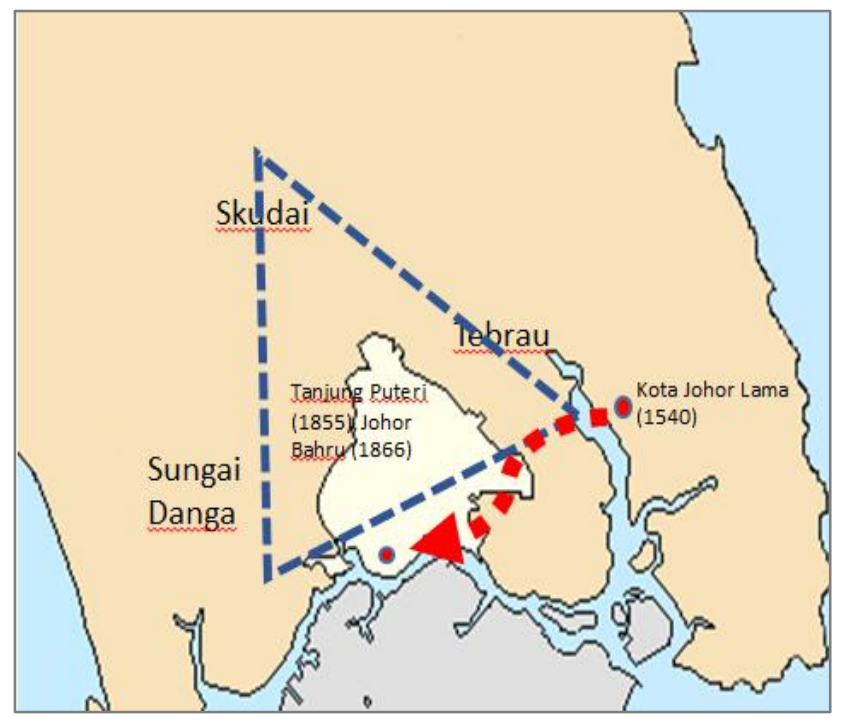

Figure 4: The history of urbanized Johor

\section{Economic and urban growth of the state}

In the 1850s, the Kangchu system - an entirely unique and efficacious land tenure system specifically for Chinese migration for agricultural land and settlement was introduced and widely implemented. With the implementation of Kangchu system, land was 20 times more developed and Johor became the world largest gambier producer in 1880 s which an evidence of economic progress in the Malay peninsula of that time. The Kangchu system together with the Kangkar settlement, a name for the formation of Chinese settlement for pepper and gambier cultivation plays vital and progressive roles in the state growth and urbanization ${ }^{[14]}$. The Malays who previously live in traditional villages had choose to live in urban village, an agglomerated type of village settlement which is closer to pekan (literally the block of shop houses, where most of economic activities took place but not in the town per se). Eventually, in the 1900s, the pepper and gambier plantation was replaced by large scale rubber plantations which again, created new type of settlement in estates and small towns. At this juncture, Malaysia has officially become an export-oriented country.

The 1960s saw the new era for palm oil considering Malaysia has become a strong foothold seeing that it was about time to further diversity its economy. Adequate rainfall, sufficient sunshine and optimal soil conditions made Johor and many other parts in Malaysia has turned to palm oil plantation and Malaysia replaced Nigeria as the number one exporter and producer in the world in 1966 and 1971. It was a viable alternative to rubber and palm oil production has become the major sector in nation's industrialization. As much as 40 FELDAs settlement was opened in Johor making it the third highest producer in the country after Sabah and Sarawak. Another breakthrough in agricultural economy for Johor in the 1960s was pineapple production. Between 1960s and 1970s, Johor has produced the most pineapple in the country and has contributed to the nation's economic development and growth of other supporting economic activities such as packaging, transportation, and other value-added activities. In fact, Malaysia has become the top three pineapple producers in the world during this period.

The 1970s saw the most rapid growth of economic, population and physical development in Johor and Malaysia. Manufacturing and production have transformed Malaysia and most of the state in the west coast of peninsular Malaysia such as Selangor, Penang, Melaka and Johor from the capital accumulation of FDI inflows. 
For Johor, the focus of manufacturing was on steel and shipping. The shift from agriculturally based to manufactured based has great implication to urbanization. The urbanization rate of Johor was $26.2 \%$, fifth position among other states in Malaysia. Rural to urban migration has contributed to rapid urban population of Johor. Thus, municipal townships have expanded, for housing estates and suburban areas has already replacing villages and agricultural areas.

Then in the $1980 \mathrm{~s}$, commodity price fell, and the state government continue to focus on manufacturing and domestic production as a method of generating employment and encouraging growth. The manufacturing sectors constantly grows and diversified with electrical and electronics $(\mathrm{E} \& \mathrm{E})$ manufacturing where Johor was one of three main centers with sustained level of FDI. The highest foreign-owned firms are Japan (48\%), Singapore (35\%) and the United State of America (6\%). There were over 4,700 firms and employs some 330,000 workforces between 1980s - 2000s in Johor and E\&E is the largest sub sector in terms of

Table 4: Johor economic and urban transformation 1850s - 2010s [14]

\begin{tabular}{|l|l|l|l|l|l|l|}
\hline Prior to 1850s & 1850s - 1880 & 1880s - 1900s & 1900s - 1960s & 1960s-1970s & 1970s -2000s & 2000s \\
\hline $\begin{array}{l}\text { Primary forest, } \\
\text { traditional } \\
\text { agricultural }\end{array}$ & Gambier & $\begin{array}{l}\text { Pepper and } \\
\text { Gambier }\end{array}$ & Rubber & $\begin{array}{l}\text { Pineapple and } \\
\text { Palm Oil }\end{array}$ & $\begin{array}{l}\text { Commodity, } \\
\text { manufacturing and } \\
\text { domestic production }\end{array}$ & $\begin{array}{l}\text { Oil \& Gas } \\
\text { FDigh-driven investment } \\
\text { High-tech production } \\
\text { Trade }\end{array}$ \\
\hline $\begin{array}{l}\text { Rural and river } \\
\text { settlement }\end{array}$ & $\begin{array}{l}\text { Kangkar and } \\
\text { traditional } \\
\text { village }\end{array}$ & $\begin{array}{l}\text { Pekan and } \\
\text { urban villages }\end{array}$ & $\begin{array}{l}\text { Estate and } \\
\text { small town }\end{array}$ & $\begin{array}{l}\text { New Village } \\
\text { FELDA } \\
\text { settlement }\end{array}$ & $\begin{array}{l}\text { Municipal } \\
\text { townships }\end{array}$ & Regional city \\
\end{tabular}

\section{Key government and agencies' role on growth}

They are few agencies that play important roles for the formulation of economic growth. The first is the Johor State Economic Planning Unit (UPENJ), the agency in authority for policy formulation and development planning. The UPENJ is responsible to monitors international and national investments in Johor, formulate economic plan and sectoral policy and engage partnership and privatization projects, and profit-generating initiatives. They produce a five-year economic plan on planning, coordinating and executing economic activities between government and private sectors. Another agency that in charge for promotional and advocacy of investments is the Johor State Investment Center (JSIC), is responsible to promote foreign and local investment in the manufacturing and service sector, undertake planning for industrial development, evaluate applications for manufacturing licenses and permits, and to assist local exporter to develop and expand their export market.

But the most significant agency that contributed to the economic and development growth of the state of Johor Corporation formerly known as the State Development Economic Corporation or JCorp. Johor Corporation was established as a public enterprise in 1968 coinciding when the Federal Government had introduced the New Economic Policy - a two-point-saw strategic blueprint to fostering nation building and adjusting employment, investment, output and export earnings ${ }^{[15]}$. Prior to year 2000s, urbanization rate in Johor was almost two third (63\%) and Johor Bahru has been granted a city status and most of the districts in Johor has municipal status such as Batu Pahat, Muar, Kluang, and Segamat.

The Johor State Structure Plan 2030 has reported, for the period of 2010 to 2015, Johor was the fourth largest contributor of GDP $(9.2 \%)$ to the Malaysian economy with an average annual growth rate (AAGR) at 5.9\%. Based on the population, the GDP per capita for Johor increased USD5683 (2010) to USD7323 (2015) with AAGR of 5.2\%. In general, the economic growth of Johor was led by manufacturing with $30.7 \%$, followed by agricultural sector $(14.9 \%)$, commerce $(12.5 \%)$. By saying economic growth and agglomeration capitalized urban growth and expansion, that being the case of rapid urbanization in Johor. Table 4 summarizes Johor economic and urban transformation from prior to 1850 s until 2010s.

Table 5: Proposed and On-Going Urban Development/ Redevelopment in Iskandar, Johor [16].

\begin{tabular}{|l|l|l|l|l|l|}
\hline Project & Size & Location & Cost & Theme & Completion \\
\hline $\begin{array}{l}\text { Pengerang Integrated } \\
\text { Petroleum Complex }\end{array}$ & $\begin{array}{l}54,363 \\
\text { acres }\end{array}$ & Pengerang & USD6.7b & Refinery and petrochemical & 2020 \\
\hline Pengerang Eco-Industrial Park & 61.8 acres & Pengerang & USD370 mil & Eco-industry & 2021 \\
\hline Ibrahim International Business & 250 acres & Johor Bahru Central & USD5b & Urban redevelopment & 2025 \\
\hline
\end{tabular}

economic disproportion. Thus, their vision and missions reflecting NEP, which was geared to achieve economic inequity by positioning the Malays in the economic cake. Among the key projects being carried out by Johor Corporation are the Ibrahim International Business District (IIBD) - designed to transform Johor Bahru City Center into a metropolis of a world stature, Pengerang Industrial Park - an eco-industrial park, B5 Johor Street market, Tebrau City - redevelopment of former army camp into integrated township and Arena Larkin sport city (Table 5).

Specifically, for Iskandar region, the key player of Iskandar Malaysia's economic development is the Iskandar Region Development Authority (IRDA). IRDA was formed under the IRDA Act 2007, Act 664 and it is technically a federal agency which come under the purview of Prime Minister's Department prior to 2018. However, because of the interest of the state of Johor, Iskandar Malaysia is jointly chaired by the Prime Minister and the Menteri Besar of Johor. Currently IRDA is positioned under the Government Investment Companies Division (GIC), Ministry of Finance. The 2,200 square kilometer region that was established in 2006 is responsible for policy formulation, investment promotion and facilitation, and mainstreaming development. IRDA has achieved so many progresses and making Iskandar region grown by leaps and bounds, even surpassing its key economic target and rolling out the implementation of various programs. 


\begin{tabular}{|l|l|l|l|l|l|}
\hline District (IIBD) & & Business District & & & \\
\hline Arena Larkin & 102.7 acres & Mont Austin & USD87 mil & Sports city & 2020 \\
\hline Tebrau City & 382.7 acres & Tebrau & USD1.16b & Integrated Township & 2022 \\
\hline B5 Johor Street Market & 5.8 acres & Tampoi & USD22 mil & Queen Victoria Market & 2020 \\
\hline
\end{tabular}

\section{Determinants of urban growth in Iskandar, Johor}

Iskandar has all the determinants of urban growth: spatial externalities; human capital; agglomeration economy; technological innovation; and institutional reform; that reflected by the GDP in the range of $7.5 \%$ annually (RM47 billion in 2012). Dogan and Stupar ${ }^{[17]}$ explains, urban development redevelopment and mega project as catalyst are essential in an expanding market economy, which capitalize urbanization and growth. Iskandar has entered second stage of development and several initiatives to create growth opportunities and moving implementation. The early phase of Iskandar Malaysia's development also witnessed the implementation and completion of key infrastructures projects such as new roads and highway - Eastern Dispersal Link (EDL), Senai Desaru Highway, Iskandar Coastal Highway as well as major roads and irrigations projects around the capital. Iskandar also has done so much on institutional reform such the implementation of smart growth concept that focuses on flagship zones as development areas; transformation and regeneration program for Johor Bahru central business district; and provide fiscal and non-fiscal incentives to direct development to specific areas.

The largest catalyst project is a 54,363-acre Pengerang Integrated Petroleum Complex (PIPC), it was one big step in creating value to the downstream oil and gas value chain in the south of Peninsular Malaysia. The project will house oil refineries, naphtha crackers, petrochemical plants, liquefied natural gas (LNG) import terminals and a regasification plant. New high value and high demand products and by-products create a more dynamic and progressive oil and gas industry in Malaysia. This will generate economic growth and moving up the value chain. To complement PIPC operations, another downstream oil and gas project was designed as part of Pengerang master plan for supporting maintenance, repair and overhaul work. The 61.8-acre Pengerang Eco Industrial Park PEIP is located side by side with PIPC also serve as a human capital development through technical and vocational education training city.

An urban redevelopment and rejuvenation project of Johor Bahru central business district named Ibrahim International Business District (IIBD) was planned to propel Johor Bahru as a world class business district and the fulcrum of business, investment and entrepreneurship. The planning process behind the 250-acre IIBD has considered economic, social and environmental components, with the aim to ensure quality and sustainability urban environment. Another redevelopment scheme that initiated as a privatization project to cater for integrated township including affordable housing is the 382.7-acre Tebrau City that was previously a Malay, Ranger and Special Force Regiments Majidee Camp before being handed over for land swap. With sustainable land use and density planning, both redevelopment projects endow spatial externalities and sought to avoid urban shrinkage and depopulation of Johor Bahru central.

Simultaneously, being the capital of Johor, Iskandar Malaysia stimulates territorial interest as a result of proximity and urban expansion - gaining optimal benefits from spillovers and agglomeration economies from neighboring Singapore that subsequently create urban growth and expansion. A research by Konstadakopulos ${ }^{[18]}$ on the element of continuity in the markets, the element of dynamic synergy and turnover of the human capital or labor forces has produced an agglomeration economy for both as a result of the proximity of Singapore-Johor. On a daily basis, 220,000 vehicles crossing both the Causeway and the Second Link with 127,600 (58\%) are motorcycles, 79,200 (36\%) cars, 2,200 light trucks (1\%), 4,400 heavy trucks (2\%), 1,100 taxis $(0.5 \%)$ and 5,500 buses $(2.5 \%)^{[19]}$. The group of users of these crossings are (from highest to lowest) workers, school-going commuters, shoppers, and logistics providers or business providers. This shows how large economic agglomeration and economic complementarity beneficial for Iskandar.

The similar case for technological innovation and human capital: new firm needed to be in technology district because in the vicinity, the speed of technological transformation and the investment in technological innovation are much higher ${ }^{[20]}$. In case of Iskandar Malaysia, clearly it has great potential and has become the regional location of choice for knowledge and innovation. Iskandar has several higher institutions operating in EduCity, Medini such as Newcastle University Medicine Malaysia, University of Southampton Malaysia, University of Reading Malaysia, Raffles University Iskandar, and Marlboro College Malaysia and also University of Technology Malaysia (UTM) and Southern University College in Skudai and UiTM in Bandar Seri Alam and this certainly will stream up innovation and technology concentration.

Table 6 shows some of the private initiative projects in Iskandar, Johor indicating the size, location, cost, theme and the completion date of the project.

Table 6: Private initiatives projects in Iskandar, Johor

\begin{tabular}{|l|l|l|l|l|l|}
\hline Project & Size & Location & Cost & Theme & Completion \\
\hline EduCity & 305 acres & Medini & USD55 mil & Higher education hub & 2020 \\
\hline Legoland Malaysia & 76 acres & Medini & USD180 mil & Family theme park & 2012 \\
\hline Pinewood Iskandar Malaysia Studio & 30 acres & Medini & USD420 mil & Production studios & 2014 \\
\hline Johor Premium Outlet & 27 acres & Kulai & USD9 mil & Premium Outlet & 2011 \\
\hline
\end{tabular}

\section{The development vision}

\section{The development vision of Johor}

Johor placed between two powerful regional hubs: Greater Kuala Lumpur and the island city-state of Singapore. Greater Kuala Lumpur is an alternative term to Klang Valley, and has a more précised geographical referenced, which covers by 10 municipalities with an area of 1,078.49 square miles (2,793 square kilometers). The context Greater Kuala Lumpur was first coined by Bunnell et al. ${ }^{[21]}$ in 2002. But the precise geographical boundary was set by the Economic Planning Unit, Prime Minister Department. The context is similar to Greater London and Greater 
Toronto in term of describing larger conurbation of the original capital. According to PwC's World in 2050 Report, Greater Kuala Lumpur not only serve as the national growth conurbation, but it has evolved to become a global city that bridge Asia and the world.

Singapore - a South East Asia (SEA) global powerhouse has been a progressive knowledge-based services economy. The country has one of the highest per capita income in the world with an outstanding economic prosperity and wealth. Thus, it is not unusual for Singapore to be one of the wealthiest countries in Asia because their government actively taking part in steering the nation's economic development and endure to position itself into the challenging global economy. Therefore, an understanding of urbanization of Greater Kuala Lumpur and the spill-over of Singapore investment into its surrounding region, is essential to this research because the consequences of the role of the city and increasing global population fostered undesired development.
In the regional development context, National Physical Plan has identified Greater Kuala Lumpur and neighboring state capital of Seremban as the National Growth Conurbation (see Figure 5). The Kuala Lumpur Growth Conurbation was aimed to provide for a potential population of 10.4 million or $37 \%$ of the Peninsular Malaysia population, somewhat equal to six time the population of Kuala Lumpur in 2005 which is 1.6 million ${ }^{[22]}$. These large conurbation and relative population have already transformed Greater Kuala Lumpur as a regional commercial and financial hub, attracting investors and business to expand their operation here. However, again according to the Federal Department of Town and Country Planning (2010) ${ }^{[22]}$, an in-depth analysis for major issues of Kuala Lumpur Conurbation is desperately requires to be addressed is the spatial planning concern, predominantly mixed uses and higher density in brownfield area. This has forced lower density development to the periphery. Another concerned issue is transportation especially in view of environmental context whereby carbon emission has quadrupled in urban areas in the last 10 years.

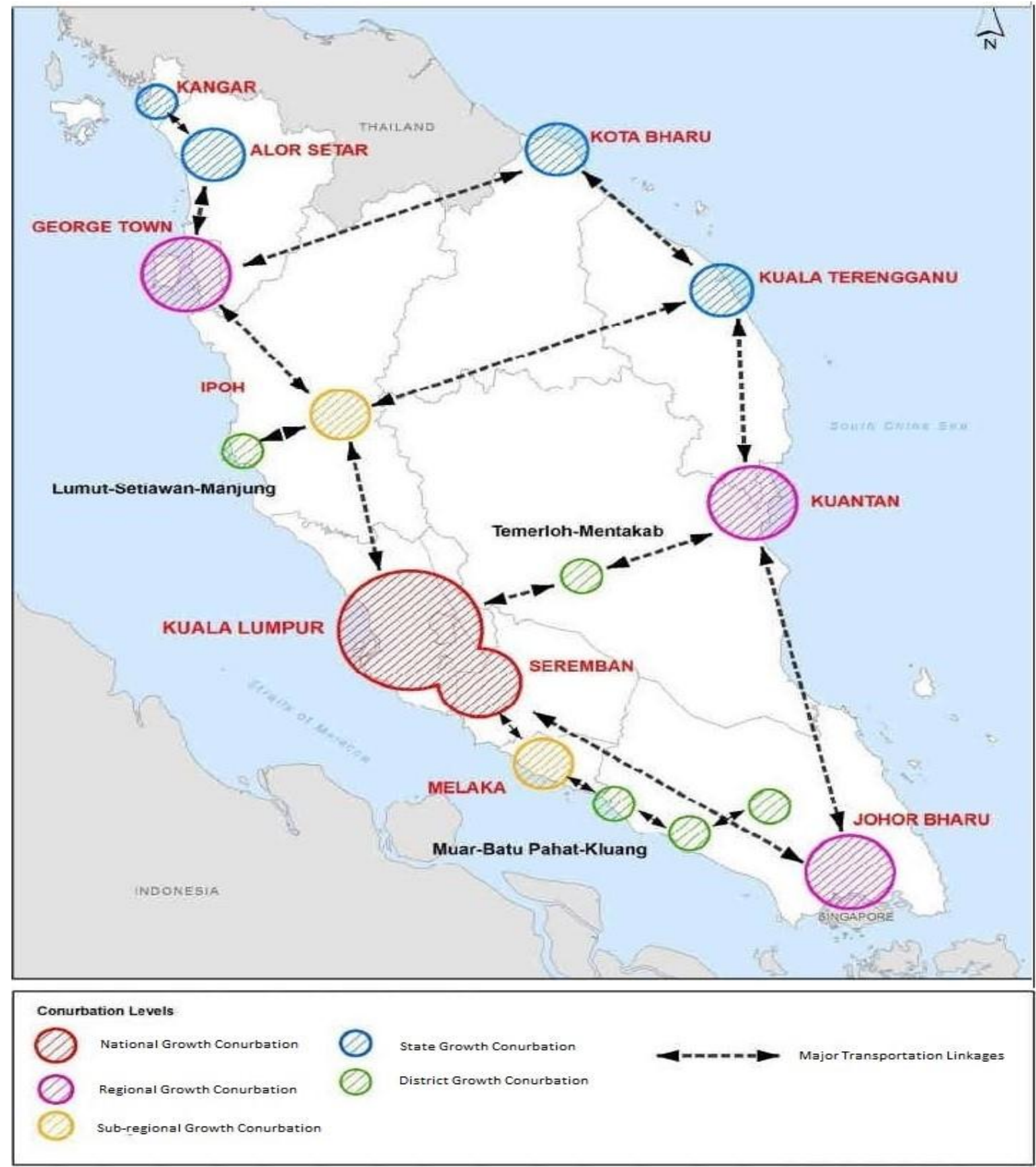

Figure 5: Urban Hierarchy Linkages Map [22]. 
Being a neighbor to Singapore, Johor has enjoyed extensive benefit in so many ways - from the agglomeration of economy where handsome investments in manufacturing sector pour in, to the spatial externalities where properties are securely purchased - has result in rapid urbanization. Singapore's FDI to Johor amounts to RM864.69 million in $2018^{[5]}$. However, Greater Kuala Lumpur (representing the Federal Government) will continue to play major roles in regulating this process because Malaysian urban policies have the tendency to embrace the capital region ${ }^{[21]}$. Johor does not seem to have financial capacity nor leadership to position itself in the global marketplace. Dependency towards the Federal government financially and politically has limit Johor to freely policy making, planning and execution.

Land use pattern in Johor generated predominantly by economic growth and urbanization together with increased population pressure and have resulted in widespread of built-up area. The rapid growth has produced significant transformation from rural to urban features in Johor. Land use change of Johor in the first phase (1991 to 2001) is compared with the second phase (2001 to 2015). Southern Johor has received one of the highest built-up land use change. The whole of Johor's built-up areas increased 370\% from 1991 to 2001 and in 2015 it was ten times than in 2001. The typical process of urbanization is a contradiction with the sustainable development: the expansion of the urban land use - and continue to change - leading to decreased agricultural, rural and forest area.

However, in Johor, agricultural land relatively has not much change with $4 \%$ decreased from 1991 to 2001 and gain $3.4 \%$ from 2001 to 2015 . This is because the state government believe the agricultural sector is still important to the economy and deserves attention because of the large number of people dependent on it. Thus, agriculture sector remains strong, and it is still needed for the food security and easy supply of essential food.

The obvious land use change is barren land, increased $381 \%$ from 1991 to 2001. However, the trend reverses from 2001 to 2015 and shrink $78.4 \%$. Major attributes for barren land are bare soil, gravels, rocks, or loose and shifting sand. In some case, barren land consists of cultivated land. Thus, barren land is temporary land use to prepare for new planting or land clearance to displace non-builtup area to built-up area. This is due to the much rapid urbanization in the first phase. Forest was also greatly decreased with $27 \%$ in the first phase, and further $6.6 \%$ decreased in the second phase. It may involve a geographic displacement of forest clearing across state through trade in agricultural and forest products. The displacement in land use stems from a growth in demand that cannot be met through national production. Table 7 shows the land use in Johor from 1991-2015.

Table 7: Land use in Johor 1991 - 2015 [23]

\begin{tabular}{|l|l|l|l|l|l|l|}
\hline \multirow{2}{*}{ Land use } & $\mathbf{1 9 9 1}$ & $\mathbf{2 0 0 1}$ & $\mathbf{2 0 1 5}$ & \% \\
\cline { 2 - 7 } & Hectares & $\%$ & Hectares & $\%$ & Hectares & 60.9 \\
\hline Agricultural & $1,162,106$ & 61.2 & $1,111,179$ & 58.5 & $1,155,455$ & 2.2 \\
\hline Barren land & 52,071 & 2.7 & 198,634 & 10.5 & 42,555 & 10.0 \\
\hline Built-up area & 18,833 & 1.0 & 69,338 & 3.7 & 190,666 & 0.15 \\
\hline Mines & 6,758 & 0.36 & 10,934 & 0.58 & 2,848 & 3.1 \\
\hline Waterbody & 10,986 & 0.58 & 33,867 & 1.8 & 59,012 & 23.6 \\
\hline Forest & 647,854 & 34.1 & 474,657 & 25.0 & 448,072 & \\
\hline
\end{tabular}

Johor strategic growth plan was formulated to achieve the development vision of Johor which is to become a high-income state and an ideal destination for investment and quality of life. The development vision also promotes participation of the community, accompanying the public and the private sector. The vision is supported through: creating a competitive and viable ecosystem; development of high skill workforces; advanced technology and infrastructure provision; progressive and sustainable growth; and an efficient and responsive public service. The strategic growth plan is intended to have a balance growth throughout the state, and by strategically assign every district with their own major economic sector (Table 8).

In the urban hierarchy context, Johor has three level of township: regional township, capital township and municipal or provincial township ${ }^{[23]}$. Johor Bahru conurbation is the only regional township, also as the capital of the state, with economic and administrative influence beyond regional boundary and population around 1.5 to 3 million. Then they have 9 capital townships and 25 provincial townships. The strategic growth plan and the urban hierarchy could have impact on the spatial and temporal pattern of urbanization. Thus, the size of the capital and the provincial township was planned to become more even with every district having their own economic sector. This is in line with the first pillar of Johor SSP 2030 to overcome future challenges: to achieve dynamic and balanced growth in the south conurbation and outside the conurbation.

Table 8: Economic sector according to district [23]

\begin{tabular}{|l|l|l|}
\hline District & Development Theme & Economic sector \\
\hline Johor Bahru & Asia's home for business & International trade, manufacturing, pharmaceutical, healthcare \\
\hline Kulai & Connecting Johor to the world & Information and communication technology, manufacturing, logistic \\
\hline Kota Tinggi & Coastal jewel & Tourism, agricultural biotechnology, petrochemical, oil and gas \\
\hline Mersing & Naturally splendid & Ecotourism, fisheries and marine activity, agricultural, light manufacturing \\
\hline Pontian & Southern sanctuary & Eco tourism, fisheries and maritime activity, light manufacturing \\
\hline Batu Pahat & Manufacturing and processing nucleus & Manufacturing, food processing, agro-tourism \\
\hline Muar & Aspiring hub for talent and knowledge & Education, entrepreneurship training, manufacturing, heritage tourism, agricultural \\
\hline Kluang & Growing with the land & Eco tourism, agricultural, manufacturing \\
\hline Segamat & Agricultural powerhouse & Agricultural, eco and agro-tourism, manufacturing \\
\hline Tangkak & Crossroad of culture and adventure & Lifestyle and adventurous tourism, light manufacturing, agricultural \\
\hline
\end{tabular}

Development vision of Iskandar Malaysia
As discussed in Section 4.3, Iskandar region has a package of growth determinants. One of the substantial commodities for 
Iskandar region to grow is the availability of land. In the initial development of Iskandar in 2006, from the total area of 220,000 hectares, $60 \%$ of Iskandar land use is agriculture, while only $15 \%$ is built up areas. Forest including mangrove and river basin make up the rest of the land use. It was initially planned to accommodate from 1.5 to 3 million population in $2025^{[24]}$. With a vision towards becoming a strong and sustainable metropolis of international standing, Iskandar has put their effort to provide a resilient ecosystem, anchored by 9 economic sectors to achieve environmental conservation and carbon reduction; strong and resilient economic growth; supports social development and enhance the quality of life; and becoming one strong region.
Iskandar was initially planned to be the second multimedia super corridor, becoming the dynamic regional corridor through spatial management and good governance by 2025. The establishment of Iskandar Regional Development Authority (IRDA), an ad hoc agency formerly under the purview of Prime Minister's Department, was to coordinate the policy formulating of Iskandar consolidating the federal and the state government. The first Comprehensive Development Plan 2006-2025 (CDP) was implemented, and the focus are more on physical development of five flagships namely the Johor Bahru city center, Nusajaya (was later renamed Iskandar Puteri), Western Gate Development, Eastern Gate Development, and Senai - Skudai (see Figure 6).

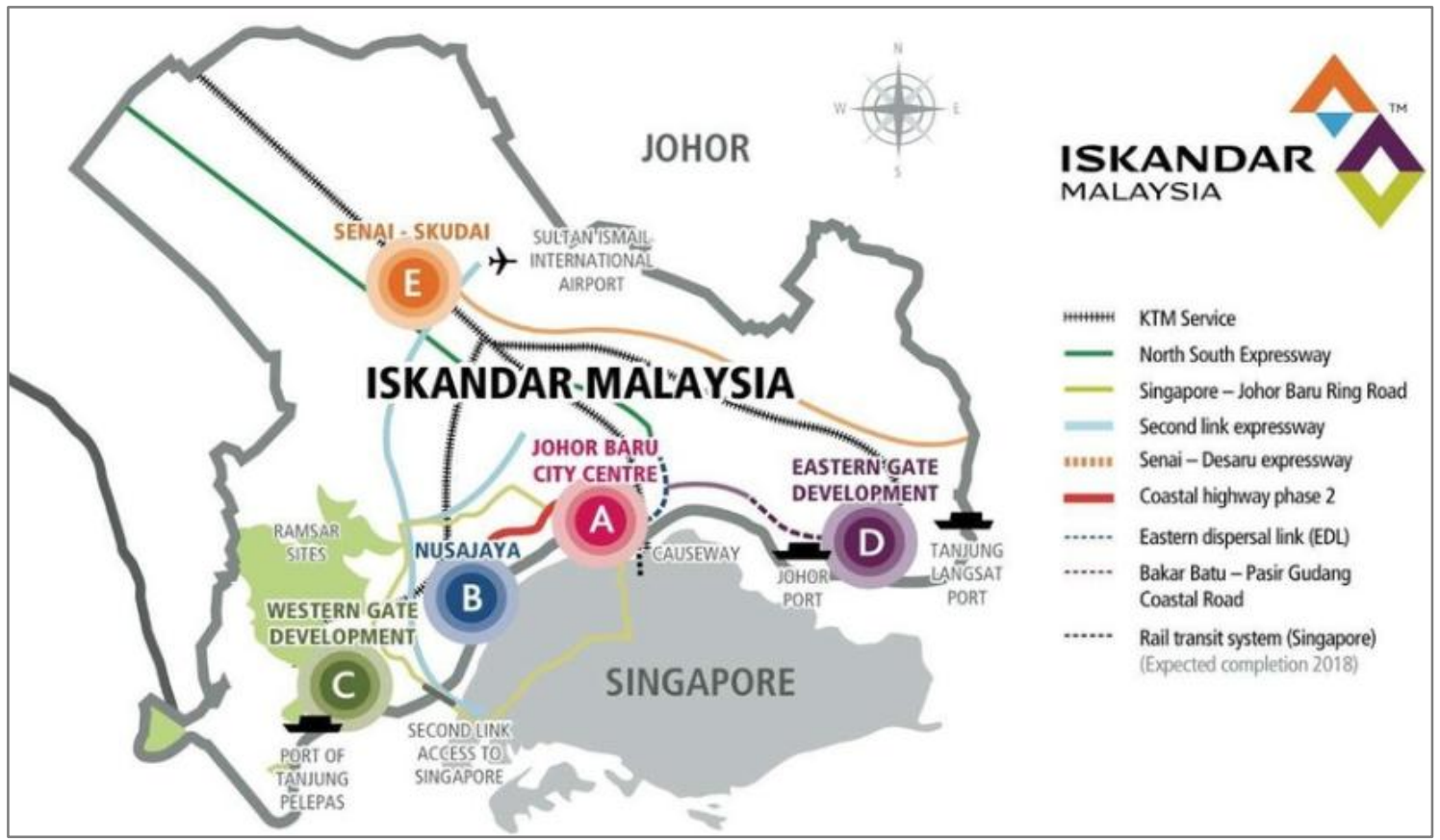

Figure 6: Iskandar Malaysia and 5 flagships development [2].

The first phase in the CDP focused in three flagship zones along the straits of Johor (JB, Nusajaya and Pasir Gudang) but most investment are concerted in Nusajaya as it has the largest undeveloped land use. Nusajaya will be developed as the new administrative center with firms, landmarks, institutions, educations and residential areas as to meet with urban expansion, knowledge spillovers, technological innovation and institutional reforms. While Kota Iskandar is the new administrative center for the state government that house the state legislative assembly, the state secretary office and other state departments is part of the institutional reform, whereas Medini Iskandar is the new CBD. Medini is a mixed-use urban development that features retail centers, community centers, theme parks, eco parks, private education hub (EduCity), private healthcare facilities and many more. EduCity was planned to enrich the $R \& D$ firms by giving initiatives to place competitive international universities as a twopoint saw initiative to promote technological innovation in Iskandar to attract high technology firms.

In the second blueprint, CDP II 2014 - 2025, Iskandar continues to be developed as a holistic ecosystem and aim to become a Sustainable Metropolis of International Standing, supported by three main strategy: wealth generation; resource optimization and low carbon; and wealth sharing and inclusiveness. Wealth generation help to create a strong and resistant economy through regional economic growth derived from technological innovation and knowledge based human capital. Resource optimization and low carbon safeguard the region from environmental degradation and natural resources exploitation through sustainable urban development and lifestyle, while wealth sharing and inclusiveness through spatial planning development to achieve a resilient and inclusive society in Iskandar. Iskandar has given all the effort that would heighten their environment and socioeconomic wellbeing and position Iskandar as a competitive global region.

\section{Urbanization and urban growth pattern in Iskandar region}

In this paragraph, the urbanization and urban growth pattern is discussed in relation to the development plans, and the development vision of the state and the Iskandar region. The greatest issue is the absence of the growth boundary. Along with these have been the rapid land use change and agricultural land encroachment, low-density and non-mixed-used development, and the height of environmental change and degradation.

\section{The Growth Boundary of Iskandar Malaysia region}

The 3rd National Physical Plan (NPP-3) has blasting statement on sustainable development and planning as their key principle, in achieving livable and resilient nation. In the case Iskandar region, the result has been, a rapid spread of built-up urban areas, with a 
filling in, at lower densities, of the entire region, denying a sustainable urban growth development. The fact that a conurbation having economic relationship and experiencing population growth to form a continuous developed built -up area has developed outside the envisaged planning, resulting in a leapfrog and haphazard growth. And yet, efficient urban planning requires the spatial extent of urban expansion and boundary demarcation ${ }^{[25]}$ also known as urban growth boundary. The delimitation of an urban growth boundary assists an orderly urban growth expansion, optimize urban spatial development and reduce the risk of environmental degradation.

\section{Land use change and agricultural land encroachment}

Land use pattern in Iskandar in 2005 in the pre regional corridor time was predominantly agriculture land and covers $70.2 \%$. The main attributes for agricultural land were palm oil plantation $76.3 \%$ and rubber plantation $12.2 \%$. Built up areas are mostly to be found in Johor Bahru central district, low-rise built-environment made up of linked houses and two/three storey building along Federal Route 1 (main road connecting from Johor - Singapore causeway to Kuala Lumpur, up to the north of peninsular Malaysia) and Federal Route 3 (main road connecting from Johor running along east coast of Malaysia). Built up areas are also concentrated in Skudai, located northwest of JB, a medium dense capital township largely grew contributed because of the presence of Universiti Teknologi Malaysia. Built up areas are also concentrated in the northeast of JB - Pasir Gudang, another capital township developed due to the proximity of Pasir Gudang port and heavy industrial areas surrounding it.

Land use change in Iskandar in 2013 is predominantly due to growing built up areas previously taking up $16.7 \%$, now taking up $26.4 \%$. Built up areas in 2013 are now more spread especially to the previously 'greenfield' in Iskandar Puteri (Table 9). Thus, agricultural land decreased to $60.0 \%$ of Iskandar region. Apart from palm oil plantation, the 'greenfield' area was partly Gelang Patah and Pulai settlement with several relocated traditional

Table 10: Mega-gated Residential Development ${ }^{[22,28]}$.

\begin{tabular}{|l|l|l|l|}
\hline Residential & Size & Location & Units (est.) \\
\hline Horizon Hills & 1200 acres & Iskandar Puteri & 1,713 \\
\hline East Ledang & 275 acres & Iskandar Puteri & 582 \\
\hline Ledang Height & 360 acres & Iskandar Puteri & 458 \\
\hline Puteri Harbor & 688 acres & Iskandar Puteri & 1,980 \\
\hline Danga BayWaterfront & 616 acres & Danga Bay & 2,200 \\
\hline
\end{tabular}

Iskandar also features several low densities residential for upper class households. This has turned the sustainable urban development that was frequently applaud in the CDP as selfcontradictory. Iskandar Puteri (previously Nusajaya) development are consisting of luxury mega-gated residential communities such Horizon Hills, Puteri Harbour, Danga Bay Waterfront, East Ledang and Ledang Heights (see Table 10). Except for Puteri Harbor and Danga Bay Waterfront, these wealthy suburban bungalows styled development is considered sprawl development because of their extreme low density (50 population per hectare), car-dependence layout with low connectivity road network and non-mixed used villages of Kampung Tiram and Kampung Paya Mengkuang, and a swamp forest in Sungai Pulai and Sungai Redan. This explained the decreased of forest previously taking up $12.0 \%$ and later shrinks to $11.0 \%$. Consequently, the expansion of urban land use leading to decreased of agricultural, rural and forest area. Another type of land use change in Iskandar is open space area, doubled from $1.1 \%$ in 2005 to $2.6 \%$ in 2013 . This is highly due to the initiatives from IRDA to build more urban parks and range to ease the urban pressure of densely populated Iskandar.

Table 9: Land use in Iskandar, 2005 and 2013. Source: IRDA 2016

\begin{tabular}{|l|l|l|l|l|}
\hline \multirow{2}{*}{ Land use } & \multicolumn{2}{|l|}{$\mathbf{2 0 0 5}$} & $\mathbf{2 0 1 3}$ \\
\cline { 2 - 5 } & Hectares & \% & Hectares & \% \\
\hline Agricultural & 119,302 & 70.2 & 106,332 & 60.0 \\
\hline Built up area & 9,725 & 16.7 & 47,119 & 26.4 \\
\hline Forest & 20,337 & 12.0 & 19,485 & 11.0 \\
\hline Open space & 1,935 & 1.1 & 4,525 & 2.6 \\
\hline
\end{tabular}

\section{Low density and non-mixed-use development}

Higher density and more compact city designs prevented automobile dependent because it produces higher parking cost, reduce transport distances and generated higher levels of transit service ${ }^{[26]}$, while mixed used development increased mobility and encouraged equal access to public service ${ }^{[27]}$. Iskandar Malaysia by comparison is a medium-density conurbation with 5,936 people per kilometer square ${ }^{[23]}$. Many Asian cities retain a rather highdensity character, but with slightly difference nature from city to city or region to region. Some of the highest densities cities in the world are to be found in Asia such as Manila, Mumbai and Dhaka ranging from 28,508 to 41,515 people per kilometer square. For regional cities or conurbation, Tokyo - Yokohama conurbation that consist of 8 municipalities has 4,700 people per kilometer square while Greater Jakarta that consists of 6 municipalities has 10,200 people per kilometer square. Thus, positioned Iskandar between the two. development, imitating American 1950s post WW II suburbs ${ }^{[29]}$. Low density and conventional zoning land use are associate with environmental degradation such as higher fuel consumption as the vehicle miles travelled (VMT), and higher energy consumption, and it goes against Iskandar's vision. On the contrary, Iskandar also promotes quality living for their residences. For this reason, there is options for several suburban styled development to be built. Of course, high density living have the downsides and concerns, such stress of overcrowded population, traffics and hygienic issue ${ }^{[30]}$. Figure 7 shows the key development in Iskandar. 


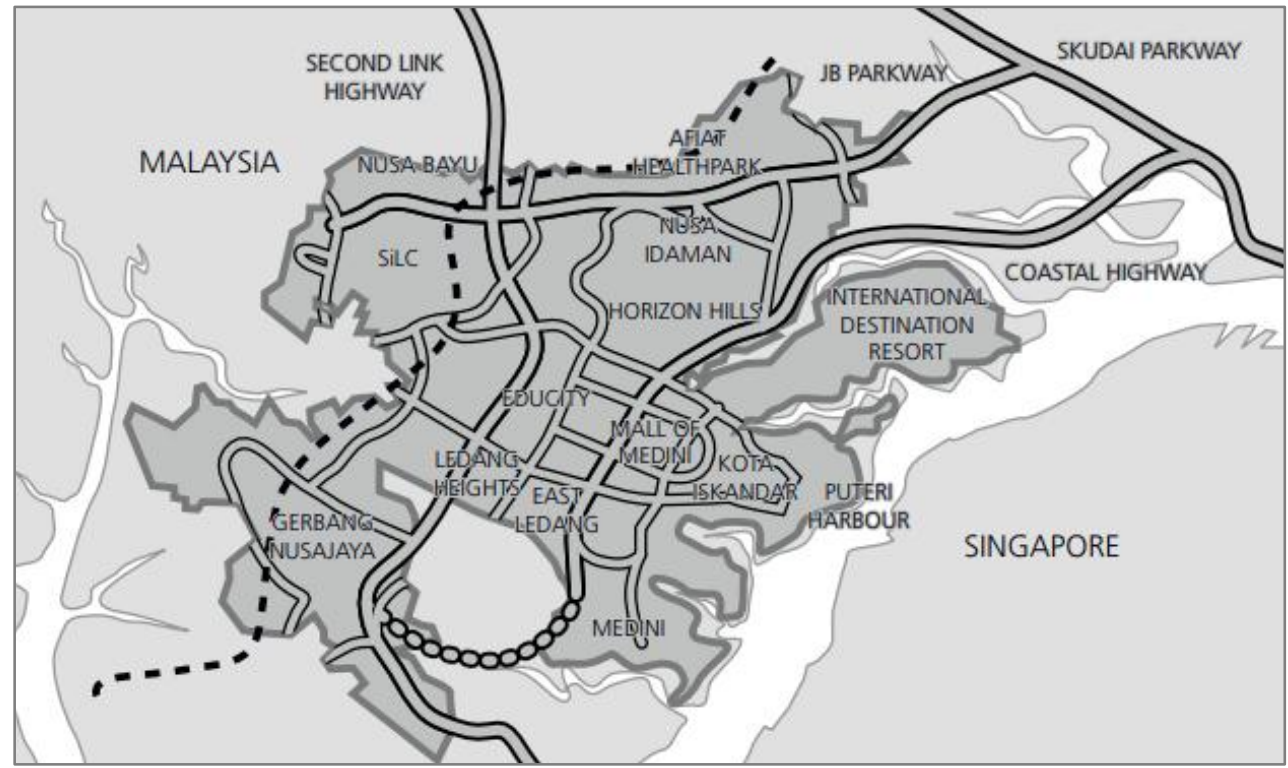

Figure 7: Key Development in Iskandar Puteri, Iskandar [28].

\section{The height of environmental change and degradation}

The CDP was above and beyond promoting sustainability in their vision through policies, strategies and planning statements. However, in the execution stage there are some unfortunate contradictory. The Sungai Skudai and Johor Strait waterfront Danga Bay was an environmentally fragile 110-acre mangrove forest that has to make way for Iskandar Coastal Highway and Danga Bay development. Hundreds of mangroves inhabitant's species including endangered species of milky stork - white plumaged stork that was around estimated about 5,000 presence are now rarely can be seen. Development took place amidst objection from many stakeholders. This is one evidence of lack of environmental awareness in planning decision.

Rapid and persistent urbanization has notable environmental change and degradation ${ }^{[31]}$. Massive urban growth is usually accompanied by an increased burden on rural and agricultural land, due to endless energy consumption, exasperating air and water, noise pollution, and loss of agricultural productivity and encroachment of natural land. In many parts of Iskandar, especially in the previously 'greenfield' like Gelang Patah, Pulai, Pekan Nenas, Tiram, Kulai and Kelapa Sawit, has abundant of agricultural and vegetation land. The growth pattern has led to a massive land use change that steadily shrink agricultural and forest land including swamp forest.

Urbanization also responsible to the degradation of environmentally fragile land and affecting their natural ecosystem in the long run. Land use change from any natural form of land to built-up development will inevitably increase in impervious surface, which turn storm water velocity (volume, speed, direction) and content (polluted). Water velocities pose extremely high risk to flash flood and inundate. The impervious surface also transfers grease, sedimentation and other fatal contaminant to storm water that eventually enter reservoir as raw water. Density development also contribute to the quality of groundwater resources ${ }^{[32]}$.

\section{Conclusions}

This paper has outlined how the national development planning framework and its institutions work, the process of economic growth and their significant impact to urbanization in Malaysia, the contribution of Johor to the nation's growth and the development of strong and resilient regional economic, and the issues regarding urban growth pattern particularly in Iskandar.

The role the role of planning institution and the statutory development plans function to determine the extension and direction of physical and land use planning to the regional or state and local level. Through the provision of the statutory plans via the Act, the planning institutional legalized the document as main instrument on urban growth control. While in the state level, Johor has introduced mechanisms for a dynamic and balanced urban growth in the south conurbation (Iskandar) and outside the conurbation. First, the state embraced an urban hierarchy which has three level of township. Then, they introduced the Johor strategic growth plan, where they strategically assign every district with their own major economic sector. It turns out the strategy has been fruitful to the resilient economic and sustainable urban growth of Johor.

Iskandar Malaysia region which is competing with neighboring economic powerhouse of Singapore and is planned around five flagship zones is one of the most successful regional development corridors developed under the Ninth Malaysia Plan by the federal government and their investment arm Khazanah Nasional. Through their statutory development plans, CDP and CDP II, Iskandar has already considered a successful high impact development project in terms of economic growth as Iskandar has been recognized as one of the highest contributions for National Gross Domestic Project. Initially, the aim of regional development corridors was to reduce regional imbalance and to accomplish equitable growth, human capital and socioeconomic wellbeing throughout the country. Consequently, the rapid growth of regional corridors has changed the predominant land use and become catalytic agent to urban growth pattern.

On the contrary, urbanization rate and urban growth pattern of Iskandar has been the downsides for their top-down initiatives to meet with infrastructural, social and economic demand of their vision. Iskandar instead, turned out to be fronting social, economic and environment cost incurred. The absence of growth boundary result in a rapid spread of built-up urban areas, with a filling in, at lower densities, of the entire region, denying a sustainable urban growth development. The rapid land use change has effect on the decreased of agricultural, rural and forest area. The low density and 
the non-mixed used development have contributed to automobile dependent urban sprawl and increased the vehicle miles travelled (VMT). Iskandar rapid urban growth also can be perceived as notable environmental change and degradation. However, further evidence on the development of Iskandar region and on the effects of the urban growth pattern are needed to better understand the fault, if any.

\section{Funding}

The authors would like to thank Malaysia's Public Service Department for funding the research activity.

\section{Conflicts of Interest}

The authors declare no conflict of interest. The funders had no role in the design of the study; in the collection, analyses, or interpretation of data; in the writing of the manuscript, or in the decision to publish the results.

\section{References}

[1] Perveen, S.; Kamruzzaman, M.; Yigitcanlar, T. Developing policy scenarios for sustainable urban growth management: A Delphi approach. Sustainability 2017, 9, 1787.

[2] Khazanah Nasional Comprehensive Development Plan for South Johor Economic Region 2006-2025; Putrajaya, Malaysia, 2006;

[3] Federal Department of Town and Country Planning National Physical Plan 3; Kuala Lumpur, Malaysia, 2016;

[4] Economic Planning Unit Eleventh Malaysia Plan, 20162020: Anchoring Growth on People; Kuala Lumpur, Malaysia, 2015;

[5] Malaysian Investment Development Authority (MIDA) Johor's 2018 FDI surges to RM24.03 bln - exco. Bernama 2019.

[6] Malaysian Investment Development Authority (MIDA) Malaysia: Investment Performance Report 2016; Kuala Lumpur, Malaysia, 2016;

[7] Sendut, H. Patterns of urbanization in Malaya. J. Trop. Geogr. 1964, 16, 114-130.

[8] Lubis, A.-R. Sutan Puasa: Founder of Kuala Lumpur; 1st ed.; Areca Books: Penang, Malaysia, 2018; ISBN 9675719338

[9] Mohamed, Z.; Abd Kadir, Z.; Abdul Raof, N.A. Malaysia Industrial Master Plans (IMPs) and the focus on the nation technology and innovation development. J. Sci. Technol. Innov. Policy 2018, 4, 11-19.

[10] Hasan, A.R.; Letha Nair, P. Urbanisation and growth of metropolitan centres in Malaysia. Malaysian J. Econ. Stud. 2017, 51, 87-101.

[11] Yigitcanlar, T.; Sarimin, M. Multimedia Super Corridor, Malaysia: Knowledge-based urban development lessons from an emerging economy. VINE J. Inf. Knowl. Manag. 2015, 45, 126-147.

[12] PricewaterhouseCoopers (PwC) Why Greater Kuala Lumpur is the ideal business hub for regional and global companies; Kuala Lumpur, Malaysia, 2017;

[13] Mohd Nasir, F.; Aman Hashim, H. The Archaeological Architecture of Kota Johor Lama. In Proceedings of the The 2nd International Nusantara Cultural Heitage
Symposium; University of Bung-Hatta: Padang, Indonesia, 2017; pp. 85-92.

[14] Hui Ching, L.; Raja Shahminan, R.N.; Mursib, G. The settlement of Kangkar as the frontier Chinese settlement in Johor, Malaysia. Int. J. Built Environ. Sustain. 2019, $6,47-53$.

[15] Ministry of International Trade and Industry (MITI) Third Industrial Master Plan (IMP3); Kuala Lumpur, Malaysia, 2006;

[16] Civil Service Delivery Unit (CSDU) National TRansformation Programme Annual Report 2017; Putrajaya, Malaysia, 2017;

[17] Dogan, E.; Stupar, A. The limits of growth: A case study of three mega-projects in Istanbul. Cities 2017, 60, 281288.

[18] Konstadakopulos, D. Learning behavior and co-operation of small high technology firms in the ASEAN Region: Some evidence from the Singapore-Johor agglomeration Agglomeration. ASEAN Econ. Bull. 2000, 17, 48-59.

[19] Ghee, T.C.; Mooi, S.K. Addressing the Singapore-Johor Causeway Cross-borderhigh Toll Charges. In Proceedings of the 4th International Conference on Multidisciplinary Research \& Practice; Research and Scientific Innovation Society (RSIS): Gujarat, India, 2017; pp. 220-233.

[20] Paci, R.; Usai, S. Externalities, knowledge spillovers and the spatial distribution of innovation. GeoJournal 1999, 49, 381-390.

[21] Bunnell, T.; Barter, P.; Morshidi, S. Kuala Lumpur metropolitan area. A globalizing city-region. Cities 2002, 19, 357-370.

[22] Federal Department of Town and Country Planning Natioanl Physical Plan 2; Kuala Lumpur, Malaysia, 2010;

[23] Department of Town and Country Planning (DCTP) Draft of State Structure Plan 2030; Johor, Malaysia, 2018;

[24] Rizzo, A.; Khan, S. Johor Bahru's response to transnational and national influences in the emerging Straits Mega-City Region. Habitat Int. 2013, 40, 154162.

[25] Kun, J.; Chao, Z.; Yanzhao, Y.; Zhen, Y. Delimitation of urban growth boundary based on the coordination of ecology and residential activity spaces: A case study of Jinan, China. J. Resour. Ecol. 2019, 10, 518.

[26] Buehler, R.; Pucher, J.; Gerike, R.; Götschi, T. Reducing car dependence in the heart of Europe: lessons from Germany, Austria, and Switzerland. Transp. Rev. 2017, 37, 4-28.

[27] Geyer, H.; Quin, L. Social diversity and modal choice strategies in mixed land-use development in South Africa. South African Geogr. J. 2019, 101, 1-21.

[28] Tek, W.M.; Hui, Y.M.; Wei, Q.H.; Seah, I. Iskandar Malaysia: A Tale of Two Cities; Kuala Lumpur, Malaysia, 2013;

[29] Barrington-Leigh, C.; Millard-Ball, A. A century of sprawl in the United States. Proc. Natl. Acad. Sci. U. S. A. $2015,112,8244-8249$.

[30] Ng, E. Towards planning and practical understanding of the need for meteorological and climatic information in the design of high-density cities: A case-based study of Hong Kong. Int. J. Climatol. 2012, 32, 582-598. 
[31] Wei, Y.D.; Ye, X. Urbanization, urban land expansion and environmental change in China. Stoch. Environ. Res. Risk Assess. 2014, 28, 757-765.

[32] Jia, X.; O’Connor, D.; Hou, D.; Jin, Y.; Li, G.; Zheng, C.; Ok, Y.S.; Tsang, D.C.W.; Luo, J. Groundwater depletion and contamination: Spatial distribution of groundwater resources sustainability in China. Sci. Total Environ. 2 